\title{
PENSAMENTO COMPUTACIONAL NA CIDADE: UMA VIVÊNCIA DE EDUCAÇÃO ONLIFE
}

\author{
COMPUTATIONAL THINKING IN THE CITY: AN ONLIFE EDUCATION EXPERIENCE \\ PENSAMIENTO COMPUTACIONAL EN LA CIUDAD: UNA EXPERIENCIA DE EDUCACIÓN ONLIFE
}

\begin{abstract}
Janaína Menezes
Doutoranda em Educação na Universidade do Vale do Rio dos Sinos - UNISINOS ORCID: https://orcid.org/0000-0002-6789-6951.E-mail: janamenezes73@gmail.com

Eliane Schlemmer

Doutora em Informática na Educação pela Universidade Federal do Rio Grande do Sul Professora-pesquisadora titular do Programa de Pós-Graduação em Educação na Universidade do Vale do Rio dos Sinos - UNISINOS ORCID: https://orcid.org/0000-0001-8264-3234.E-mail: elianes@unisinos.br

\section{Fabio La Rocca}

Doutor em Sociologia pela Université Paris Descartes Sorbonne Professor de Sociologia na Université Paul-Valéry Montpellier III - UPVM3 ORCID: https://orcid.org/0000-0001-7635-5666. E-mail: fabio.la-rocca@univ-montp3.fr
\end{abstract}

\section{José António Moreira}

Doutor em Ciências da Educação pela Universidade de Coimbra

Professor Associado na Universidade Aberta de Portugal - UAb ORCID: https://orcid.org/0000-0003-0147-0592.E-mail:jmoreira@uab.pt

\begin{abstract}
RESUMO
Experienciar a cidade enquanto espaço de aprendizagem implica entrelaçamento de seus vários tempos, espaços e de suas dimensões humanas e não humanas, digitais, biológicas, históricas, econômicas, etc. Entender a cidade como entidade viva, complexa e comunicativa se afasta da visão antropocêntrica de mundo e instaura outras formas de comunicação, habitação e aprendizagem. Portanto, este artigo apresenta o processo de desenvolvimento de uma prática pedagógica gamificada cujo objetivo é compreender como o coengendramento dos diversos entes constituintes da cidade produz o pensamento computacional na perspectiva da aprendizagem inventiva, segundo uma proposta de Educação OnLIFE. Tal prática integra o projeto de pesquisa A cidade como espaço de aprendizagem: práticas pedagógicas inovadoras para a promoção da cidadania e do desenvolvimento social sustentável, financiado pela Fundação Carlos Chagas e pelo Itaú Social, e desenvolvida pelo Grupo de Pesquisa Educação Digital — GPe-dU, UNISINOS/CNPq. O estudo, qualitativo, apropria-se do método cartográfico de pesquisa-intervenção para produção e análise dos dados. Como resultado, apresentam-se pistas que permitem compreender a emergência do pensamento computacional para explorar a cidade, bem como a necessidade de inovação de práticas pedagógicas a partir da problematização do mundo para uma Educação conectada com a vida.
\end{abstract}

Palavras-chave: Idade; Pensamento Computacional; Educação Onlife; Gamificação.

\section{ABSTRACT}

Experiencing the city as a learning space implies interweaving its various times, spaces, and its human and non-human, digital, biological, historical, and economic dimensions, among others. Understanding the city as a living, complex, and communicative entity moves away from the anthropocentric worldview, establishing 
other forms of communication, dwelling, and learning. Therefore, this article presents the development process of a gamified pedagogical practice whose goal is to understand how the co-engagement between various constituent entities of the city produces computational thinking in the perspective of inventive learning, according to a proposal of OnLIFE Education. This practice is part of the research project A cidade como espaço de aprendizagem: práticas pedagógicas inovadoras para a promoção da cidadania e do desenvolvimento social sustentável, financed by Fundação Carlos Chagas and Itaú Social, and developed by the Digital Education Research Group - GPe-dU, UNISINOS/CNPq. This qualitative study uses the cartographic method of research-intervention to produce and analyze data. As a result, we present clues that allow us to understand the emergence of computational thinking to explore the city, as well as the need for innovation in pedagogical practices from the problematization of the world for an Education connected to life.

Keywords: City; Computational Thinking; Onlife Education; Gamification.

\section{RESUMEN}

Vivir la ciudad, como espacio de aprendizaje, implica entrelazamiento de sus diversos tiempos, espacios y de sus dimensiones, humanas y no humanas, digitales, biológicas, históricas, económicas, entre otras. Entender la ciudad como entidad viva, compleja y comunicativa se aleja de la visión antropocéntrica del mundo e instaura otras formas de comunicación, vivienda y aprendizaje. Por lo tanto, este artículo presenta el proceso de desarrollo de una práctica pedagógica gamificada cuyo objetivo es comprender cómo la coingeniería de las distintas entidades que conforman la ciudad produce pensamiento computacional desde la perspectiva del aprendizaje inventivo, según una propuesta de Educación OnLIFE. Esta práctica integra el proyecto de investigación "La ciudad como espacio de aprendizaje: prácticas pedagógicas innovadoras para la promoción de la ciudadanía y el desarrollo social sostenible”, financiado por la Fundación Carlos Chagas y por el Itaú Social, y desarrollado por Grupo de Investigación Educación Digital- GPe-dU UNISINOS/CNPq. El estudio, cualitativo, utiliza el método cartográfico de investigación-intervención para producir y analizar datos. Como resultado, se presentan elementos que nos permiten comprender el surgimiento del pensamiento computacional para explorar la ciudad, así como la necesidad de innovación en las prácticas pedagógicas basadas en la problematización del mundo, para una Educación conectada con la vida.

Palabras-clave: Ciudad; Pensamiento Computacional; Educación Onlife; Gamificación.

\section{INTRODUÇÃO}

Experienciar a cidade enquanto explorador, segundo La Rocca (2018), constitui-se como aventura de descoberta e compreensão, para olhar e observar em total imersão. A cidade, conforme o autor, é um reservatório ilimitado de experiências, um recipiente de vida que nos oferece riqueza de estímulos incomparável. Para La Rocca (2018, p. 11) “escutar”, "sentir”, "viver" e “tocar” seus espaços, seus lugares, sua arquitetura, emanam um imaginário de visões e de sensações".

No entanto, segundo Schlemmer, Oliveira e Menezes (2021), o habitar do ensinar e do aprender cultural socialmente reconhecido se desenvolve, predominantemente, nos espaços físicos geograficamente localizados das instituições de Educação Formal, herdeiras de pedagogias diretivas desenvolvidas segundo o binômio sujeito-objeto (S-O), meio-ambiente-indivíduo (MA-I), em um tempo pré-digital. Neste sentido, a cidade é 
tomada como objeto, meio-ambiente, portanto, está fora de nós, compreendida como algo que nos serve.

Segundo Di Felice (2009), ambiente e território não devem ser entendidos como coisas, mas algo vivo, entidade complexa, agente e comunicativa que propicia um aprender e ensinar estendido além dos muros das instituições e das paredes das salas de aula. Ou seja, entender a cidade como coisa viva promove a visão de um diálogo interno e externo no qual os sujeitos estão imersos na natureza e na técnica que os constitui.

Superar a distância imposta pelo pensamento dualista e separatista é importante para criarmos formas de experienciar a cidade imersivamente. A cidade é o entrelaçamento de todas as dimensões que lhe dão forma, contém vários tempos e espaços, abriga diversas esferas da vida física, digital, espiritual, humana e biológica, como local de encontro entre as pessoas, natureza, saberes, tecnologias, produtos, tradições, culturas.

De acordo com Schlemmer, Oliveira e Menezes (2021), entender a cidade como algo vivo propicia a visão de um diálogo em rede com diferentes entidades, sejam biológicas, físicas ou digitais. Nessas redes, as tecnologias digitais ampliam nossa presença na cidade e instauram outras formas de habitação e comunicação. Com essas tecnologias é possível estar acoplado de várias formas ao organismo vivo da cidade e se misturar a vários espaços físicos e/ou digitais, em tempos síncronos e assíncronos, a modificar os fluxos de comunicação de unidirecional para multidirecional.

Nesse contexto vemos a evolução da inteligência artificial, da robótica, internet das coisas, tecnologias wearables, big data, nanotecnologia, entre outras. Isso modifica nosso presente, tornando-o cada vez mais conectado, o que permite dizer que vivemos uma realidade hiperconectada (FLORIDI, 2015), na qual não faz sentido separarmos o on-line do off-line. Segundo Floridi (2015), estamos em uma sociedade “onlife”, as tecnologias digitais não estão "fora" de nós, tampouco sujeitadas ao total controle do humano, como, por exemplo, as tecnologias de Inteligência Artificial. Essa compreensão, segundo Moreira e Schlemmer (2020, p. 26) possibilita “pensar/desenhar diferentes contextos investigativos, de desenvolvimento e formação, os quais instigam a inventividade no âmbito do ensinar e o aprender", visto que o habitar e o coabitar encontra-se cada vez mais atópico, vinculado além dos espaços geográficos, mas também aos espaços digitais em rede.

\section{Pensamento Computacional e Invenção}


O interesse no desenvolvimento do pensamento computacional emerge desse habitar cada vez mais permeado pelas redes digitais, no qual entes humanos e não humanos estão em constante conectividade. Colocado em debate na comunidade científica e educacional por Wing (2006), o pensamento computacional é, segundo a autora, outro letramento, fundamental para atuar no século 21.

Wing $(2006 ; 2008 ; 2011 ; 2016 ; 2017)$ revisitou bastante sua própria definição de pensamento computacional, cunhada em 2006, que em sua versão atual (2017, p. 1), compreende-o como "processos de pensamento envolvidos na formulação de problemas e suas soluções de modo que as mesmas sejam representadas de uma forma que possa ser eficazmente executada por um agente de processamento de informações". De acordo com Wing (2006), o pensamento computacional deve estar incorporado às nossas vidas, relacionado a várias áreas de conhecimento, para além de linguagens de programação. Como ele se relaciona com a arte, a filosofia, a geografia e as demais ciências? Como se relaciona com o ambiente, com o espaço que habitamos?

A partir de 2006, o debate sobre o desenvolvimento do pensamento computacional gerou várias políticas públicas nos Estados Unidos, apoiadas por instituições como ISTE (International Society for Technology in Education), CSTA $^{2}$ (Computer Science Teacher Association) e NRC (National Research Council), bem como Royal Society ${ }^{3}$ no Reino Unido e outros países da Europa e da Ásia, a fim de desenvolver o pensamento computacional nas escolas. Estas instituições elaboraram documentos para guiar currículos de instituições escolares, porém, não há consenso entre cientistas e pesquisadores sobre o conceito de Pensamento Computacional. Contudo, existem princípios norteadores oriundos da Ciência da Computação, presentes neste processo como: pensamento algorítmico, decomposição, generalização, identificação de padrões, abstrações, avaliação, automação (UNRC, 2010; ISTE/CSTA, 2011; SBC, 2019; RAABE; BRACKMANN; CAMPOS, 2020).

No entanto, apesar de o debate sobre o Pensamento Computacional na educação se fortalecer a partir de 2006, é preciso lembrar que Papert (1972; 1980; 1994) já havia, ainda que não usasse o mesmo termo, abordado o pensamento computacional como

\footnotetext{
${ }^{1}$ Disponível em: https://www.iste.org/. Acesso em: 23 ago. 2021.

2 Disponível em: https://www.csteachers.org/. Acesso em: 23 ago. 2021.

3 Disponível em: https://royalsociety.org/. Acesso em: 23 ago. 2021.
} 
“pensamento processual” (procedural thinking) nas pesquisas que originaram a Linguagem e Filosofia LOGO. Desenvolvida no final da década de 60 e início da década 70, mas popularizada na década de 80 , permite que crianças e adolescentes criem seus próprios programas de computador, incluindo o desenvolvimento, a representação, a depuração e um conjunto de passos que podem ser executados por um objeto, representado pela Tartaruga, na linguagem LOGO, um objeto para se pensar com, no dizer de Papert.

Diante do processo de digitalização que vivenciamos, não podemos deixar de considerar, conforme Schlemmer, Di Felice e Serra (2020), que, além de humanos e tecnologias, habitam as redes biodiversidades, objetos, superfícies, dados, etc. Assim, desenvolver o pensamento computacional também implica compreendê-lo em uma dimensão além do humano ou das tecnologias, como possibilidade de estabelecer conexões não mais limitadas, segundo Di Felice (2018), a uma rede de informações transmitidas pelo computador. Trata-se de outra ecologia formada também pelo "protagonismo informativo das coisas, dos rios, das florestas, das estradas, dos algoritmos" (SCHLEMMER; DI FELICE; SERRA, 2020, p. 5).

Neste sentido, quais as possibilidades para desenvolver o pensamento computacional com as experiências vivenciadas no território da cidade, entendida como algo dentro e fora de nós, a nos constituir? Para tanto, quais metodologias e práticas pedagógicas precisam ser desenvolvidas?

A compreensão epistemológica do pensamento computacional definido por Wing é marcada pelo cognitivismo computacional que concebe o mundo como processamento de dados de entradas e saídas (inputs e outputs) através de regras lógicas do sistema cognitivo. Neste modelo a concepção cognitiva é uma representação que pressupõe sujeito e objeto como polos anteriores ao processo de conhecer, um processo de solução de problemas.

Este artigo pretende discutir a compreensão do desenvolvimento do pensamento computacional na perspectiva da aprendizagem inventiva (KASTRUP, 2001; 2005; 2010; 2015), ampliando o conceito de cognição, a fim de sustentar que conhecer não é apenas representar, mas também produzir realidade.

A aprendizagem inventiva (KASTRUP, 1999; 2000; 2001; 2005; 2010; 2015) nos ajuda a pensar a atualidade, o mundo em processo de transformação acelerada, visto que amplia o conceito de cognição ao introduzir novas questões como a criação, a invenção de 
problemas e as modulações da cognição no mundo contemporâneo. Nesta perspectiva, Kastrup (2015) compreende que as tecnologias digitais que hoje integram nosso domínio cognitivo não devem ser entendidas como meros objetos, tampouco soluções para antigos problemas, mas focos de criação de novos problemas, de novas relações com a informação, com o tempo, o espaço, consigo e com os outros.

A aprendizagem inventiva inclui a experiência de problematização revelada através do que Maturana, Varela e Dos Santos (1995) chamaram breakdowns, isto é, rachaduras no fluxo cognitivo habitual nos forçando a pensar. Para Maturana, Varela e Dos Santos (1995), o mundo perturba, e tal "perturbação", ou breakdown, corresponde, segundo Kastrup (2001), ao momento da invenção de problemas, a rachadura, uma bifurcação que abala o fluxo recognitivo habitual. Neste sentido, o conceito de breakdown é fundamental para entender que sujeito e mundo estão coengendrados ${ }^{4}$ pela ação, em um processo de transformação permanente e passível de reinvenção, pois, o aprendizado assume a forma de um círculo, cujo movimento reincide, retorna, renova, reinventa, reitera, recomeça (KASTRUP, 2005).

Portanto, como o coengendramento entre os diversos entes que compõem a cidade podem produzir o pensamento computacional na perspectiva da invenção? Para compreender esta problematização é necessário pensar em metodologias e práticas pedagógicas que traduzam esse percurso.

\section{O Contexto da Pesquisa}

A tríade pesquisa-desenvolvimento-formação, sobre a qual o Grupo Internacional de Pesquisa GPe-dU - UNISINOS/CNPq opera, produz, em uma perspectiva epistemológica reticular e conectiva (DI FELICE, 2012), metodologias inventivas e práticas pedagógicas simpoiéticas, inventivas, e gamificadas, que favorecem um habitar atópico, alinhadas à necessidade de compreender e acompanhar processos de ensino e de aprendizagem em contextos de hibridismo, multimodalidade, pervasividade e ubiquidade (LOPES; SCHLEMMER, 2011; SCHLEMMER, 2014; 2015; 2016a; 2016b; 2018).

\footnotetext{
4 Por "co-engendrado", entende-se, segundo Kastrup (2001; 2005; 2008; 2010), uma ruptura com as dicotomias sujeitoobjeto, interior-exterior, indivíduo-sociedade. Afasta-se da influência do meio sobre os sujeitos e vice-versa, visto que, nesta perspectiva, tanto sujeito como o meio se transformam e se produzem incessantemente.
} 
A prática pedagógica a ser descrita e discutida neste texto, denominada Traces in Hamburgo Velho, desenvolve-se como parte de um conjunto de práticas docentes no âmbito da Metodologia Inventiva Projeto de Aprendizagem Gamificado - PAG (SCHLEMMER, 2018)5. A prática é desenvolvida com estudantes de terceiro ano do Ensino Fundamental em uma escola de Educação Básica na cidade de Novo Hamburgo - RS, e integra a pesquisa A Cidade como Espaço de Aprendizagem: práticas pedagógicas inovadoras para a promoção da cidadania e do desenvolvimento social sustentável, financiada pela Fundação Carlos Chagas e Itaú Social desenvolvida pelo GPe-dU UNISINOS/CNPq.

Assim, temos por objetivo discutir os dados produzidos nesta prática docente, desenvolvida no território da cidade, vinculados ao desenvolvimento do pensamento computacional (PAPERT, 1972; 1980; 1994; UNRC, 2010; SBC, 2019; RAABE; BRACKMANN; CAMPOS, 2020), à aprendizagem inventiva, à hibridização de espaços urbanos e pósurbanos (DI FELICE, 2009; 2012; 2018; LA ROCCA, 2010; 2016; 2018; LEMOS, 2004; 2007; 2017) em um habitar do ensinar e do aprender conectados com a vida (SCHLEMMER, 2020; MOREIRA; SCHLEMMER, 2020).

A partir desta introdução e dos objetivos estabelecidos, apresentaremos o delineamento da pesquisa e os movimentos de construção desta prática docente advindos do método cartográfico de pesquisa-intervenção.

\section{Metodologia}

Este estudo, cuja abordagem é qualitativa, desenvolve-se segundo o método cartográfico de pesquisa-intervenção de Passos, Kastrup e Escóssia (2015).

Segundo Passos, Kastrup e Escóssia (2015, p. 10), “a cartografia propõe uma reversão metodológica”. A palavra metodologia deriva do grego metá (por meio de, através) hódos (caminho, via). Isto é, a pesquisa é um caminho (hódos) predeterminado por metas. Para os autores, a cartografia, ao propor essa reversão, transforma o metá-

\footnotetext{
${ }^{5}$ A metodologia inventiva PAG se fundamenta nas epistemologias reticulares e conectivas, sendo construída a partir de elementos presentes na Cognição Inventiva, na Metodologia de Projetos de Aprendizagem, na Metodologia de Projetos de Aprendizagem Baseado em Problemas, no Método cartográfico de pesquisa-intervenção, adaptado enquanto prática pedagógica e, no conceito e nos elementos de Gamificação.
} 
hodos em hódos-méta, aposta na experimentação do pensamento, "um método não para ser aplicado, mas para ser experimentado e assumido como atitude".

Em oposição a outros métodos de investigação - nos quais o pesquisador se mantém afastado e procura isolar o objeto de estudo - na cartografia, o pesquisador habita o território investigado. Em vez de coletar dados para analisá-los, como é de praxe em outros métodos, o trabalho na cartografia está voltado à produção de dados, pois, o processo de pesquisa faz emergir realidades que não estavam dadas à espera de uma observação.

O território da pesquisa deste artigo envolve estudantes do terceiro ano do ensino fundamental em uma escola de educação básica, no bairro de Hamburgo Velho, no município de Novo Hamburgo.

A história da cidade está ligada aos primeiros imigrantes alemães a chegarem ao Rio Grande do Sul em 1824, para os quais o governo imperial cedeu lotes de terras. Ao chegarem no território do atual município, fundaram um povoado chamado Hamburgerberg ${ }^{6}$ (Morro dos Hamburguenses), hoje bairro histórico de Hamburgo Velho7, cujo patrimônio está parcialmente tombado pelo IPHAN ${ }^{8}$.

Desde 2015, integra o currículo escolar de 39 estudantes de oito e nove anos o item Programação, para o qual são reservados 50 minutos semanais na plataforma Code ${ }^{9}$, em inglês.

Os fatos observados foram descritos em um diário de pesquisa. Registraram-se intervenções e breakdowns provocados em diferentes momentos do processo também em fotos, vídeos e áudios. Ademais, os estudantes participaram de entrevistas cartográficas.

A cartografia é orientada por pistas e não por aplicação de regras. Passos, Kastrup e Escóssia (2015) propuseram pistas, pois, durante o acompanhamento dos processos, a cartografia não poderia ter de antemão a totalidade dos procedimentos metodológicos. As pistas guiam o pesquisador cartógrafo como referência durante o percurso da pesquisa.

\footnotetext{
${ }^{6}$ Disponível em: https://novohamburgo.org/site/nossa-cidade/historia/colonizacao-hamburger-berg/. Acesso em: 23 ago. 2021.

7 Disponível em: https://www.novohamburgo.rs.gov.br/historia. Acesso em: 23 ago. 2021.

${ }^{8}$ Disponível em: http://portal.iphan.gov.br/pagina/detalhes/1639/. Acesso em: 23 ago. 2021.

9 Disponível em: http://www.code.org. Acesso em: 23 ago. 2021.
} 
O funcionamento da atenção é uma pista importante na formação do pesquisadorcartógrafo. Definida como aberta e concentrada, movimenta-se de quatro maneiras: rastreio, toque, pouso e reconhecimento atento. Esta pista está relacionada ao funcionamento da atenção durante o trabalho de campo, desde as primeiras inquietações do pesquisador até o mergulho no território da investigação.

O rastreio é um gesto de varredura do campo que visa uma espécie de meta ou um alvo móvel. Não se identifica com busca de informação. Segundo Kastrup (2015, p. 42), “a atenção do cartógrafo realiza uma exploração assistemática do terreno, com movimentos mais ou menos aleatórios de passe e repasse, sem grandes preocupações com possíveis redundâncias".

Nesta pesquisa, o movimento de rastreio surgiu de uma inquietação durante o trabalho nas aulas de programação com a plataforma Code. Embora os estudantes se sentissem muito motivados com a dinâmica das atividades na plataforma, por vezes não estava claro como o percurso de apropriação daquele conhecimento ocorria. Assim, a atenção é tocada por algo que provoca o segundo movimento.

O toque é a segunda variedade de atenção manifesta como pequeno vislumbre a acionar o processo de seleção. Algo se destaca, ganha relevo e exige atenção. O toque, segundo Kastrup (2015), pode levar tempo para acontecer, ter diferentes graus de intensidade e revelar múltiplas entradas do mapa.

Algumas indagações foram surgindo, tocando-nos e nos levando a pensar como potencializar os conceitos do pensamento computacional para os estudantes, bem como estabelecer conexões além da plataforma de programação. Chamava-nos atenção o fato de os estudantes se mostrarem muito curiosos para explorar o bairro de Hamburgo Velho, no âmbito do desenvolvimento das áreas de História e Geografia. Seria possível estabelecer aí uma conexão? A partir disto, o movimento do pouso começaria a se desenhar.

A partir do momento que algo gera a seleção e muda o direcionamento da atenção, inicia-se o movimento do pouso. No pouso, a percepção se detém e o campo se fecha, em zoom, como se o pesquisador observasse o campo por uma janela.

Isto posto, pousou-se sobre a indagação a respeito de como o currículo do terceiro ano do ensino fundamental e o desenvolvimento do pensamento computacional poderiam se coengendrar, visto que a Base Nacional Comum Curricular (BRASIL, 2017) prevê, para a 
área das Ciências Humanas, o desenvolvimento da noção de lugar em que se vive e as dinâmicas em torno da cidade, a partir da escola, do bairro e da comunidade.

A Base Nacional Comum Curricular (BRASIL, 2017) propõe a compreensão interdisciplinar sobre os diferentes grupos sociais e étnicos que compõem a cidade, bem como seus desafios culturais, ambientais, os patrimônios históricos e lugares de memória, como ruas, praças, escolas, monumentos, museus, etc. Além disso, preconiza-se o desenvolvimento das análises geográfica, histórica e espacial dos espaços percebidos, concebidos e vividos a partir de linguagens cartográficas, de diferentes gêneros textuais e tecnologias digitais, a fim de desenvolver o raciocínio espaço-temporal relacionado à localização, distância, direção, duração, sucessão e conexão. Há ênfase nos lugares de vivência, de modo que noções de pertencimento, localização e orientação se construam.

Neste sentido, quais as possibilidades de experienciar a cidade de forma algorítmica?

A partir das incursões a pé pelo bairro, o movimento do Rastreio acontece tanto por iniciativa dos estudantes quanto dos pesquisadores. Tal movimento compreende a exploração dos espaços, do conhecimento dos habitantes (humanos e não humanos) e da história da cidade.

O processo de Toque é acionado a partir da vivência de exploração no movimento de rastreio que provoca emoções, curiosidades, desejo e problematizações.

O Pouso, a indicar parada e focalização, ocorre nos aspectos da experiência do corpo, dos lugares, dos espaços, dos habitantes, das tecnologias de onde emergiram tais problematizações para se possível mergulhar na experiência, e, então, gerar o Reconhecimento Atento, a atitude investigativa diante do coengendramento e do que dele se produz como pensamento computacional, na perspectiva da aprendizagem inventiva, traduzido em um projeto de aprendizagem gamificado. A seguir, ilustramos esse percurso metodológico. 
Figura 1 - Percurso metodológico nos quatro movimentos da atenção cartográfica

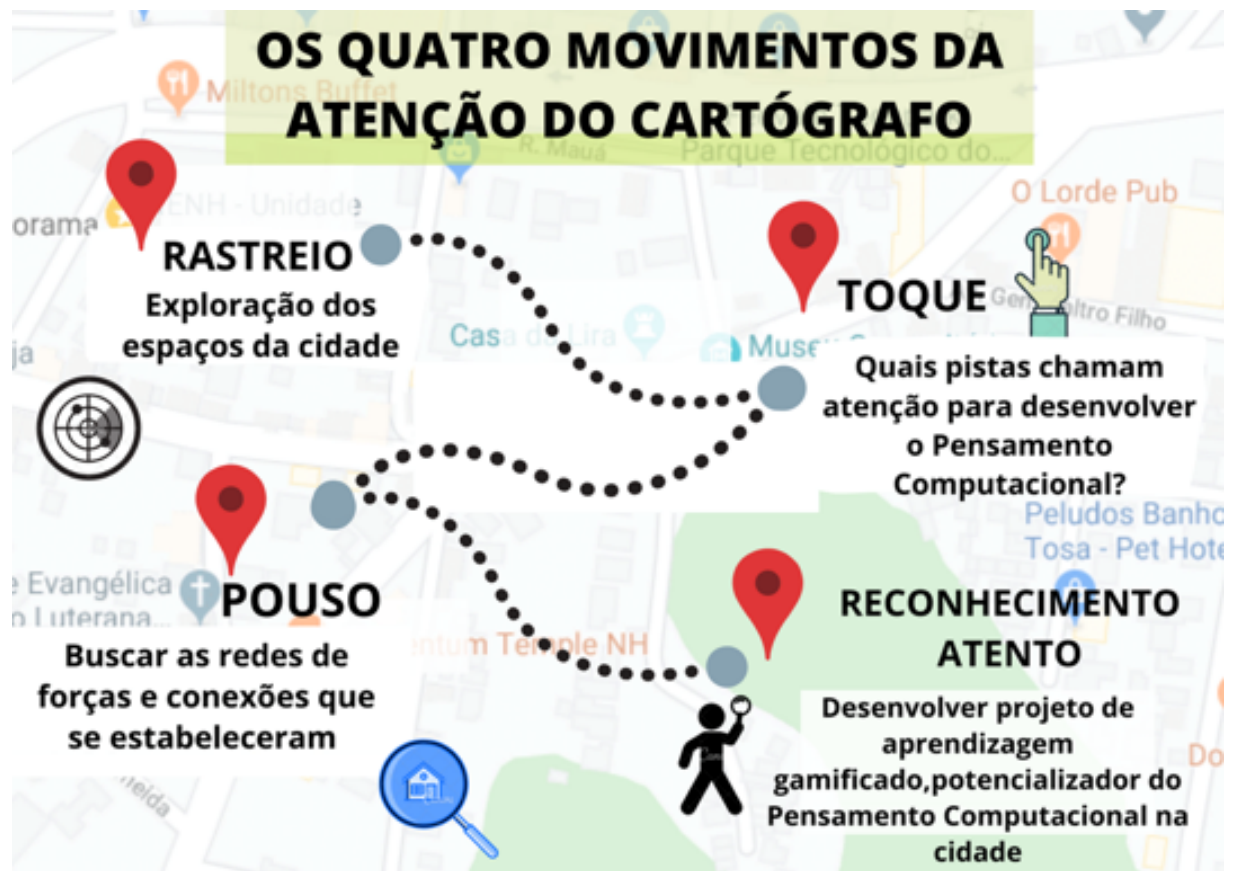

Fonte: elaborado pelos autores.

Assim, a prática pedagógica descrita a seguir parte do projeto de aprendizagem gamificado na cidade, denominado Traces in Hamburgo Velho, inspirado pela metodologia PAG (SCHLEMMER, 2018) e pelo movimento da atenção cartográfica (PASSOS; KASTRUP; ESCÓSSIA, 2009; 2015). A imagem abaixo sistematiza os elementos desta prática docente na cidade.

Figura 2 - Sistematização da prática pedagógica gamificada na cidade

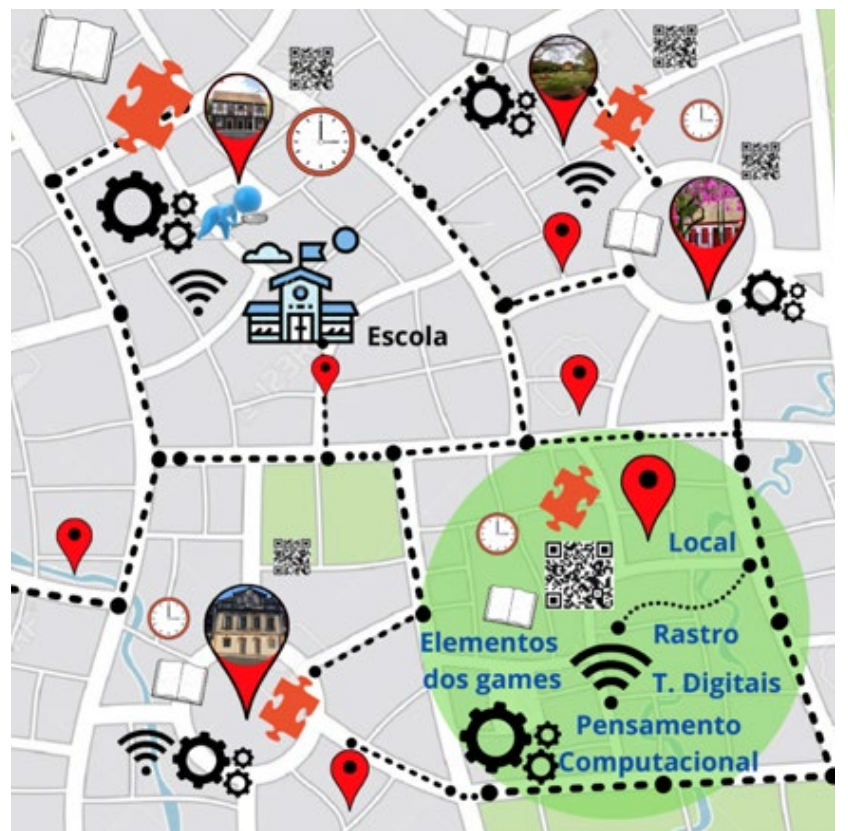

Fonte: elaborado pelos autores. 
A seguir, descrevemos uma das práticas pedagógicas oriundas do projeto Traces in Hamburgo Velho.

TRACES IN HAMBURGO VELHO — prática pedagógica gamificada na cidade

Esta vivência, com duração de quatro horas, desenvolveu-se no fim do primeiro semestre de 2019, com 39 alunos, de oito e nove anos, do terceiro ano do ensino fundamental de uma escola de educação básica bilíngue (português — inglês) no bairro Hamburgo Velho, no município de Novo Hamburgo-RS.

O objetivo era compreender a cidade como potência para desenvolvimento do pensamento computacional e contribuir para a expansão dos espaços educacionais, transcendendo o espaço físico das instituições. Os estudantes viveriam uma experiência no bairro com elementos de games durante o percurso (narrativa, missões, pistas) para elaborarem, posteriormente, seu próprio jogo baseado no que viveram.

Neste processo de materialização da experiência de campo visamos tecer os fios daquilo que acontece no plano coletivo de forças e afetos, ao demandar atitude que implica habitar o território da pesquisa. Assim, descrevemos a experiência por meio daquilo que toca e emerge deste território a fim de, em seguida, pousar a atenção nos analisadores para refletir atentamente e discutir o que a experiência suscitou.

\section{Os primeiros movimentos cartográficos}

Consideramos importante contextualizar as vivências anteriores que foram fundamentais para concepção cartográfica, em razão da trajetória percorrida pelos estudantes desde o início do ano letivo, compreendendo várias caminhadas pelos arredores da escola e do bairro, a fim de estabelecer conexões com trajetos, rotas, lugares, pessoas, história, culturas, fauna, flora, entre outros. Esta prática se desenvolveu em língua inglesa porque um dos pesquisadores é docente do idioma na instituição escolar onde a pesquisa ocorreu. Assim, transcreram-se as falas dos estudantes em português, e em inglês os códigos de programação (move forward/turn left/turn right/when you exit).

Nesses momentos a atenção do cartógrafo, tanto dos pesquisadores quanto dos estudantes, encontrava-se aberta e suspensa para fazer emergirem os movimentos da atenção cartográfica que forneceriam elementos para construção da prática pedagógica específica descrita a seguir. Para as saídas, os estudantes portavam tablets (fornecidos pela 
escola) e registravam fotos e vídeos do que Ihes chamava a atenção. Assim, durante este período, tiveram oportunidades de caminhar pelas ruas e pesquisar seus nomes, visitar museus, conversar com moradores e historiadores, observar o espaço do bairro por diferentes formas e momentos. Nessas ocasiões, todos os caminhos foram construídos em forma de códigos, através das mesmas expressões utilizadas pelos estudantes na plataforma code.org.

Ao retornar para o espaço físico da escola, pesquisadores e estudantes conversavam sobre o que Ihes havia chamado a atenção, suas descobertas, e compartilhavam fotos e vídeos. Nas imagens abaixo é possível ver o registro de algumas saídas, das visitas e dos percursos em código que os estudantes e pesquisadores construíram juntos.

Figura 3 - Estudantes nas caminhadas pelo Centro Histórico do bairro e os registros dos trajetos
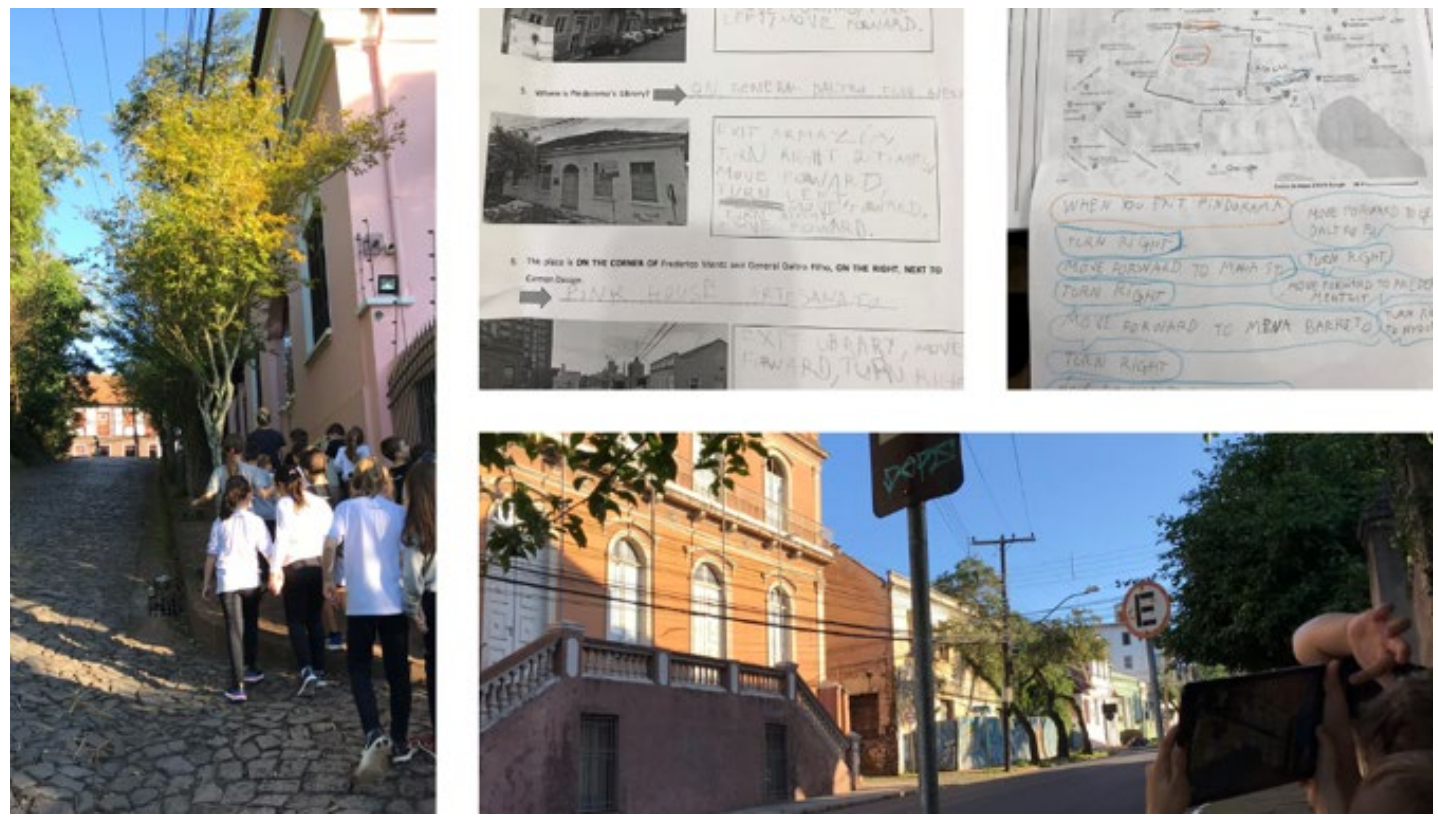

Fonte: elaborado pelos autores.

Constatou-se, nessas primeiras vivências, o interesse dos estudantes pelas ruas estreitas e arquitetura das casas construídas pelos antigos moradores, entre elas, as três casas em estilo enxaimel presentes no bairro, uma delas tombada patrimônio histórico do município ${ }^{10}$. A partir destes registros, fechamos o campo, pousamos a atenção e

${ }^{10}$ Disponível em: http://portal.iphan.gov.br/pagina/detalhes/1678/. Acesso em: 27 ago. 2021. 
construímos um grande pôster para representar o percurso com fotos e barbantes. Os alunos afixaram o pôster na sala de aula, como na figura a seguir.

Figura 4 - Estudantes construindo pôster com registros fotográficos dos rastreios pelo bairro


Fonte: elaborado pelos autores.

A partir dessa trajetória, em uma atitude investigativa diante do pouso, iniciou-se um processo de problematização e invenção de uma prática pedagógica gamificada, objeto do presente artigo, a fim de articular os elementos trazidos pelos estudantes sobre ruas, arquitetura, história da imigração, moradores, trajetos, mapas, códigos, entre outros.

Decifrando enigmas com Johann Peter Schmitt

Para representar essas experiências, os pesquisadores selecionaram (rastreio, toque e pouso) entes observados pelos estudantes durante as caminhadas no bairro (casas, placas, ruas, moradores). Embora planejada, a construção dessa prática pedagógica estava aberta ao que emergisse no momento da experiência, de modo que não tolhesse rastreios, toques e pousos imprevistos. Portanto, os pesquisadores optaram por construir uma narrativa com um personagem importante do contexto da imigração alemã, chamado Johann Peter Schmitt, um dos primeiros comerciantes de Hamburgerberg, que contribuiu muito para o desenvolvimento da região. Tal personagem deixara rastros espalhados por Hamburgo Velho, cujo trajeto os estudantes receberam a incumbência de descobrir para 
resgatar um importante objeto reservado a eles por Johann Schmitt, sob os cuidados de um morador. Assim, cada pista guardaria um enigma e, ao decifrá-los, os estudantes estariam mais perto de encontrar o objeto misterioso em Hamburgo Velho. Para tanto, precisariam montar o itinerário até esses locais por meio de uma forma algorítmica com a qual já estavam familiarizados graças ao code.org e às caminhadas pelo bairro (mova-se para frente/vire à direita/vire à esquerda). Abaixo, apresentamos no mapa o percurso e a localização dos rastros.

Figura 5 - Mapa com a localização do Rastros pelo bairro de Hamburgo Velho

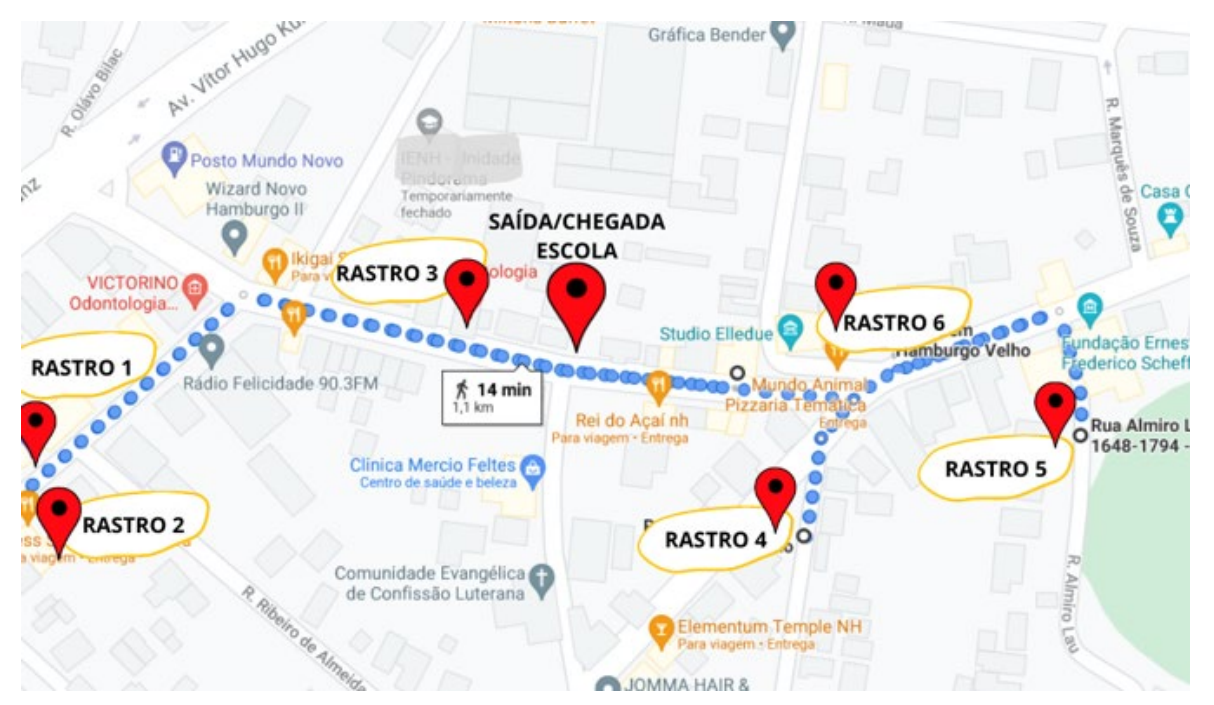

Fonte: elaborado pelos autores.

No dia desta prática, os pesquisadores deixariam para os estudantes uma carta de Johann Peter Schmitt com a narrativa e a missão. Haveria também quebra-cabeças das imagens de algumas fotos (dos registros dos alunos), um tablet com leitor de QRcode, um mapa das ruas e outro para a construção dos trajetos (rastros), bem como moedas (que representavam os contos de réis). 
Figura 6 - Materiais para a prática pedagógica


Fonte: elaborado pelos autores.

O quadro abaixo ilustra o planejamento da prática pedagógica gamificada, inspirado no Cosmograma da Gamificação (SCHLEMMER, 2018).

Quadro 1 - Organização da Prática Pedagógica inserida no projeto Traces in Hamburgo Velho

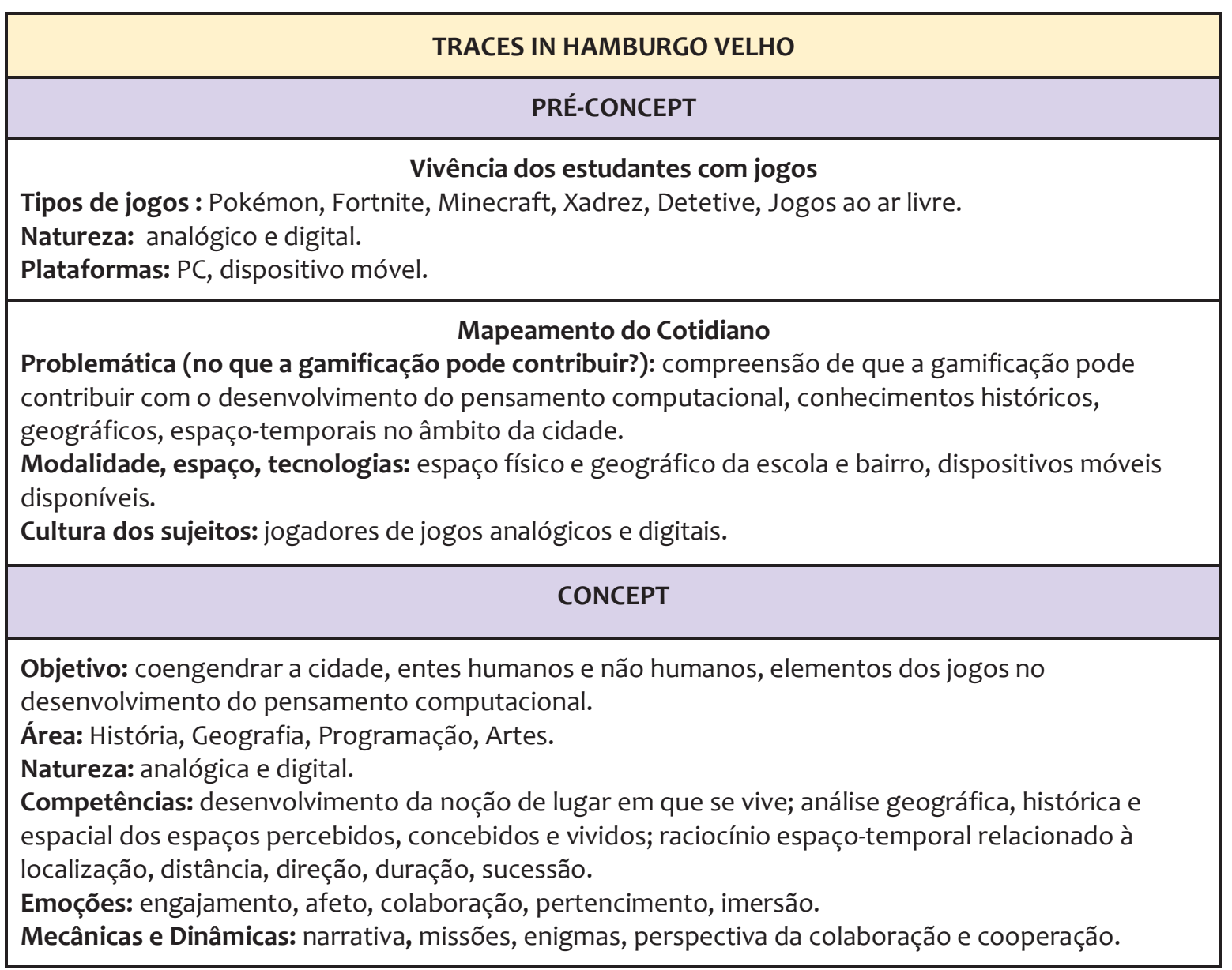




\begin{tabular}{|c|c|}
\hline \multicolumn{2}{|r|}{ DESENVOLVIMENTO } \\
\hline $\begin{array}{l}\text { Narrativa e } \\
\text { personagem }\end{array}$ & $\begin{array}{l}\text { Guten Morgen! Meu nome é Johann Peter Schmitt. Lembram-se de mim? } \\
\text { Hamburgerberg agora é Hamburgo Velho e tem muita história. Deixei alguns } \\
\text { rastros no bairro para conhecerem-no melhor. Sua missão é encontrar esses } \\
\text { rastros. Em cada lugar encontrado há enigmas para resolver. Cada vez que os } \\
\text { solucionarem, receberão moedas - contos de réis (como era chamado nosso } \\
\text { dinheiro!). Mantenham as moedas! Vocês precisarão delas mais tarde. No fim da } \\
\text { jornada, ganharão um objeto especial! Nossa jornada começa no portal aberto } \\
\text { por vocês aqui na escola. }\end{array}$ \\
\hline Missão & $\begin{array}{l}\text { Montar os trajetos de forma algorítmica para encontrar os lugares onde Johann } \\
\text { Peter Schmitt deixou enigmas (QR Codes) e buscar o objeto misterioso. }\end{array}$ \\
\hline Tecnologias & $\begin{array}{l}\text {-tablets com leitor de Qr Codes; mapa do bairro (frente) e espaço para construir } \\
\text { os trajetos (verso); moedas (contos de réis); -quebra cabeças com a imagem dos } \\
\text { lugares que precisam descobrir }\end{array}$ \\
\hline Espaços & $\begin{array}{l}\text { Saída do “Portal” - porta antiga da Biblioteca da escola que já fez parte da } \\
\text { primeira prática pedagógica do projeto. } \\
\text { Rastro } 1 \text { - antiga loja de tecidos, cuja neta do proprietário será uma pista viva. } \\
\text { Neste local há a primeira placa da loja que traz escrito "Fazendas e Miudezas". } \\
\text { Enigma: "Sou uma loja que vende Fazendas e Miudezas. O que é isto?". } \\
\text { Rastro } 2 \text { - em frente da loja, há uma das mais antigas construções do bairro, hoje } \\
\text { restaurada. Há ano de construção grafado no topo do prédio, muito comum } \\
\text { antigamente. Enigma: "Sou uma casa muito antiga. Você sabe calcular a minha } \\
\text { idade?". } \\
\text { Rastro } 3 \text { - parede grafitada da escola onde há cálculos matemáticos. Enigma: } \\
\text { "Meu resultado é 14.". } \\
\text { Rastro } 4 \text { - Evangelische Gemeindeschule, a primeira escola fundada pelos } \\
\text { imigrantes em 1832. Enigma: "Que tipo de escola eu sou? O que significa } \\
\text { "Gemeinde"?". } \\
\text { Rastro } 5 \text { - Rua Almiro Lau, antiga rua que encontra o Parque Luiz Henrique } \\
\text { Roessler (Parcão), Unidade de Conservação da cidade e cujas terras pertenciam } \\
\text { ao lote de Johann Peter Schmitt. Enigma: "Sou uma rua, me ache no mapa. Onde } \\
\text { eu termino?". } \\
\text { Rastro } 6 \text { - Armazém, local onde há muitos objetos antigos e onde se encontrará } \\
\text { o objeto especial de Johann Peter Schmitt. Enigma: "Você está com sede? Peça } \\
\text { uma Spritzbier. Como você vai pagar?". } \\
\text { O objeto especial é uma mala antiga com materiais como fita adesiva, palitos de } \\
\text { madeiras de diversos tamanhos, bala de goma, massa de modelar, palitos de } \\
\text { plástico, um livro e um copo plástico. Dentro da mala há um envelope. }\end{array}$ \\
\hline
\end{tabular}




\begin{tabular}{|c|c|}
\hline $\begin{array}{l}\text { Mecânica e } \\
\text { dinâmica }\end{array}$ & $\begin{array}{l}\text { Os enigmas foram feitos com QR codes, impressos e fixados nos } \\
\text { estabelecimentos pelos pesquisadores com a devida autorização dos } \\
\text { proprietários. } \\
\text { No "Portal" onde o percurso inicia, os alunos se organizam em grupos de três } \\
\text { integrantes. Ali mesmo, cada grupo recebe um quebra-cabeça com a imagem do } \\
\text { Rastro 1. O desafio é montar o quebra-cabeça. Cada Rastro trará pistas sobre o } \\
\text { trajeto (mapa verso). } \\
\text { Ao descobrir o lugar, marcamos o seu ponto no mapa (frente). As pesquisadoras } \\
\text { e os estudantes montarão juntos o trajeto, caminhando e vendo, por exemplo, } \\
\text { quantos passos devem dar para frente, ou quando é o momento de virar } \\
\text { (esquerda/direita) na rua e registrar o percurso (mapa verso) até chegar ao local. } \\
\text { No local, haverá um QR code com um enigma. Os estudantes, com os tablets, são } \\
\text { desafiados a ler o código, interpretá-lo e resolver o enigma para conseguir } \\
\text { receber a pista do Rastro } 2 \text { e uma moeda de conto de réis, e assim por diante. } \\
\text { Ao chegar no último rastro, haverá uma pista viva para ajudá-los a decifrar o } \\
\text { enigma. Ali precisarão usar as moedas que forem coletadas para comprar um } \\
\text { item no Armazém e receber o objeto deixado por Johann Peter Schmitt (mala } \\
\text { antiga organizada pelas pesquisadoras). }\end{array}$ \\
\hline $\begin{array}{c}\text { Acompanhamento } \\
\text { e avaliação }\end{array}$ & Diário de percurso; fotos, áudios, vídeos, entrevistas. \\
\hline
\end{tabular}

Fonte: elaborado pelos autores.

Como havia duas turmas, a prática aconteceu em dias separados para cada grupo. Famílias e estudantes receberam as orientações necessárias quanto à autorização de saída, os materiais e as roupas adequadas. A instituição providenciou professores auxiliares e funcionários responsáveis pela proteção dos estudantes, apesar da boa segurança e do trânsito calmo na área do centro histórico. Descreveremos, a seguir, com maior detalhamento, o percurso por dois dos rastros e ilustraremos os demais com imagens.

Após todos os estudantes chegarem à escola, abriu-se o envelope para leitura da carta de Johann Peter Schmitt. Os estudantes conseguiram interpretar o "portal” como a porta da biblioteca com acesso para a rua. Gradualmente, diante da excitação por iniciar o percurso, os alunos se organizaram e cada grupo recebeu o primeiro quebra-cabeças, que conduziria ao Rastro 1. 
Figura 7 - Estudantes montando o quebra-cabeça que os levaria para o Rastro 1 e seu enigma
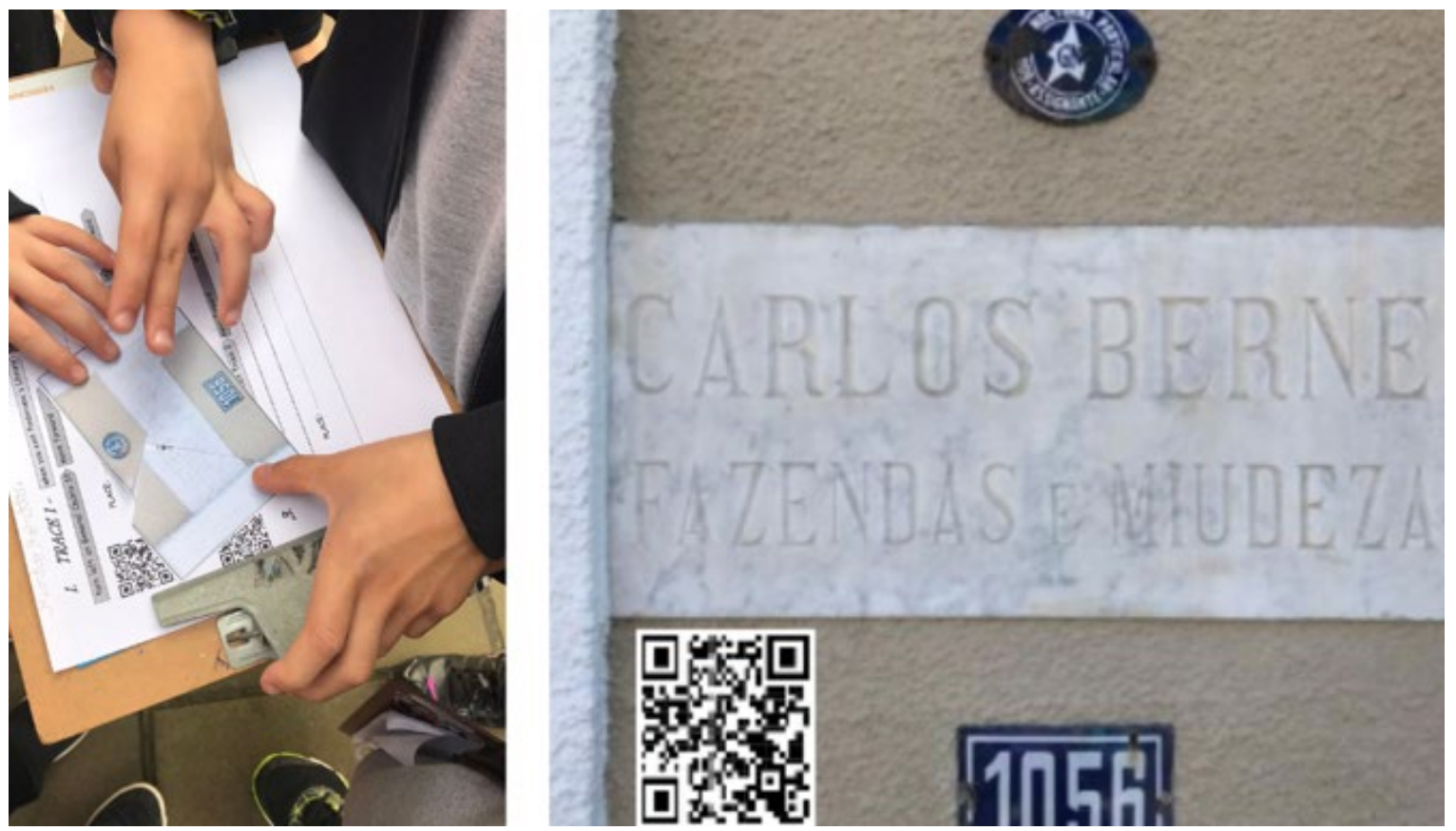

Fonte: elaborado pelos autores.

A pista do primeiro lugar levava a uma placa. Os estudantes leram a placa, mas não souberam onde ficava. No verso do mapa havia uma pista para o Rastro 1: "Move forward on General Daltro Filho Avenue, turn left, move forward on General Osório Avenue". No entanto, precisaram contar os passos para saber a distância a percorrer entre uma avenida e outra. Porém, como saber quando parar? Um dos estudantes diz "Precisamos olhar as placas das ruas, quando aparecer General Osório a gente para e vira."

Os discentes percorreram a Av. General Osório a contar os passos e observar os locais. Ao encontrar a placa, registraram o trajeto e o número de passos até ali. Com os tablets, leram e desvendaram o enigma em $Q R$ code, achando o vídeo com a neta do Sr. Carlos Berner, fundador da loja, que contava como se faziam roupas antigamente.

Depois solucionarem o enigma do primeiro rastro, receberam dos pesquisadores uma moeda (conto de réis). O próximo quebra-cabeça, deixado por Johann Peter Schmitt, levaria ao Rastro 2. Este, conforme a figura abaixo, era uma casa muito antiga em frente ao local onde todos estavam naquele momento. Os estudantes foram indagados sobre como fazer para chegar até a casa. Alguns dizem "Move forward", outros "Move forward, stop in the house.". Assim, montaram o trajeto contando os passos necessários até a casa. 
Figura 8 - Estudantes decifrando o Rastro 2
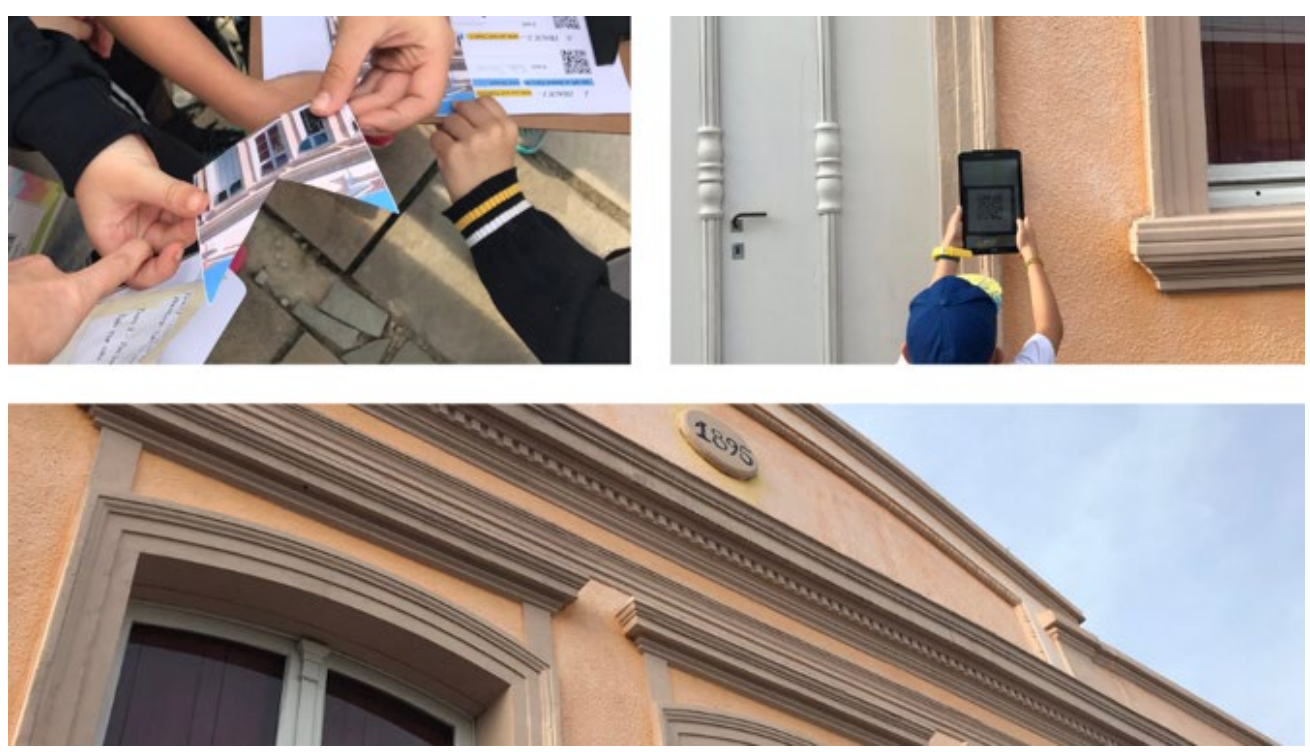

Fonte: elaborado pelos autores.

Na porta da casa leram o $Q R$ code com o segundo enigma. Primeiramente, ficaram um pouco confusos, até que alguns apontaram para a parte de cima da casa: "Ali, nas casas de antigamente eles colocavam o ano.”. Assim, verificaram que no topo da casa havia o ano 1895. "Como vamos descobrir a idade desta casa?", perguntaram os pesquisadores, ao que os estudantes responderam "Tem que fazer uma conta de menos.". Eles, então, armaram o algoritmo do cálculo de 2019 - 1895. É um tipo de subtração que ainda está em desenvolvimento, pois, envolve milhar. Contudo, os grupos tentaram resolver o problema: “104”; “Não, 124”; “124 anos de idade”, e assim decompuseram o cálculo e estabeleceram o processo de subtração com transporte e retorno. Desta forma, receberam o próximo quebra-cabeça até o Rastro 3, além de outra moeda de conto de réis. Os registros do percurso dos Rastros 3 até 6 estão nas seguintes imagens:

Figura 9 - Da esquerda para a direita: Rastro 3 (parede com grafite), Rastro 4 (Evangelische Gemeindeschule), Rastro 5 (Rua Almiro Lau), Estudantes registrando o percurso, Rastro 6 (Armazém) 


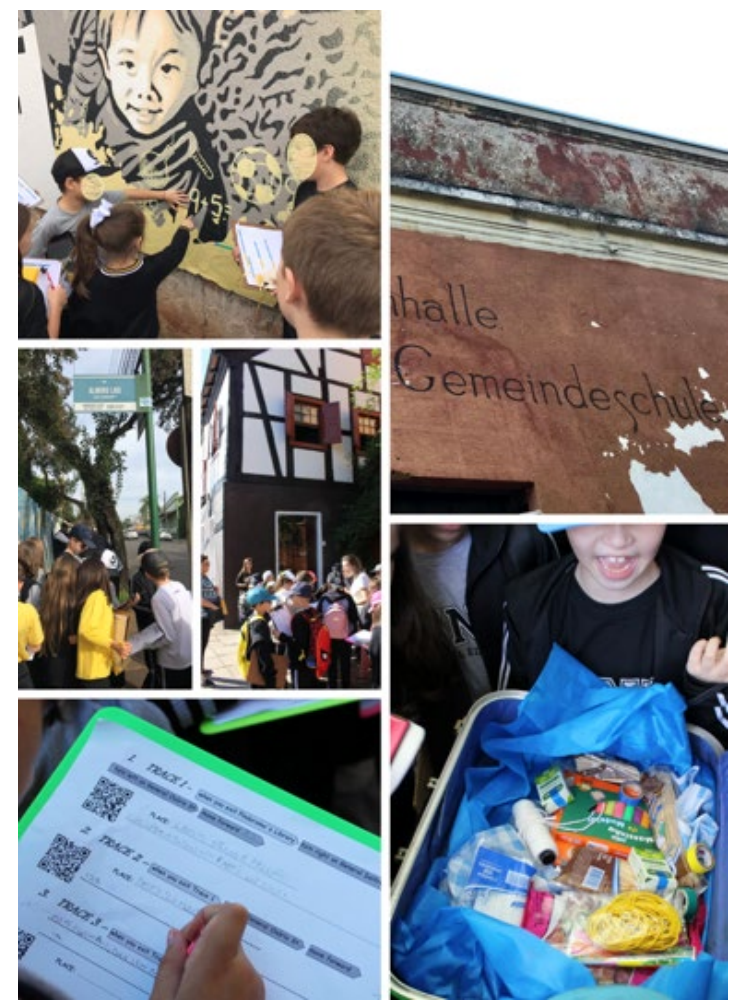

Fonte: elaborado pelos autores.

No local do último rastro, a dona do estabelecimento, outra pista viva, convida todos a entrarem e mostra o Spritzbier, refrigerante preparado pelos descendentes de alemães até hoje. Cada grupo usa seus contos de réis para "comprar" a bebida e a experimentam no armazém. Na sequência, perguntam à dona do Armazém: “E o objeto especial do Johann Peter Schmitt?". Então, recebem uma mala antiga com uma carta do lado de fora. A carta, escrita pelo personagem da narrativa, saudava-lhes por cumprirem a primeira parte dos Traces in Hamburgo Velho! Em seguida, dizia-lhes que tinham ainda outra missão: povoar Hamburgerberg e construir mais casas enxaimel para os próximos imigrantes. Para isso, precisariam usar o material contido na mala. Nesta havia balas de goma, vários tipos de palitos de madeira, fita adesiva, massa de modelar, barbantes, papel, sucata, etc.

Neste momento, ao encontrar o objeto deixado pelo personagem da narrativa, a manhã de percurso pelas ruas do bairro ${ }^{11}$ chega ao fim. No dia seguinte, ao retornar para a escola, os registros dos rastros pelas ruas e a experiência pelo bairro foram discutidas entre pesquisadores e estudantes. Imprimiram-se fotos dos locais visitados para colarem-nas no

\footnotetext{
${ }^{11}$ Disponível em: https://www.youtube.com/watch?v=230Cbzl5Wlk\&t=2s. Acesso em: 27 ago. 2021.
} 
pôster, onde os estudantes traçaram mais percursos. A próxima seção contém análise dos resultados da prática pedagógica.

A construção das casas com os materiais da mala encontrada foi realizada logo após. Sua dinâmica e seus resultados serão apresentados e discutidos em artigo futuro.

Traces in Hamburgo Velho - o jogo dos estudantes

Em outra etapa do projeto, as vivências desencadeadas pelas várias práticas pedagógicas fizeram emergir a cocriação da parte dos estudantes e dos pesquisadores envolvidos no Traces in Hamburgo Velho. Nesta proposta, os estudantes em movimento cartográfico observaram todos os locais indicados no pôster e seus trajetos. Deste rastreio, em uma discussão em grande grupo, selecionaram-se os locais que provocaram maior interesse, sobre os quais pousou a atenção. Deste pouso, emergiu o reconhecimento atento às experiências, que resultou no desejo dos estudantes de construir outros rastros e apresentá-los para os pais na Feira de Projetos da escola, no mês seguinte, com o objetivo de compartilhar suas experiências pelo bairro Hamburgo Velho. O Quadro 2 apresenta a proposta do jogo com o exemplo de um rastro (foram seis para cada turma), bem como suas imagens.

Quadro 2 - Percurso do jogo elaborado pelos estudantes

\begin{tabular}{|c|l|}
\hline \multicolumn{2}{|c|}{ Traces in Hamburgo Velho } \\
\hline Narrativa e Missão & $\begin{array}{l}\text { "Olá, durante os nossos passeios em Hamburgo Velho, esquecemos uma } \\
\text { foto nossa por lá. Você precisa seguir nossos rastros, resolver os enigmas e } \\
\text { achar nossa foto. Quando achar, você pode ficar com ela." }\end{array}$ \\
\hline Tecnologias & Realidade Aumentada, Google Maps, Qr Codes, Boomerangs. \\
\hline Rastros e Enigmas & $\begin{array}{l}\text { Seis Rastros em QR Codes.Exemplo: } \\
\text { Rastro 1- QrCode - Ache nosso rastro entre a foto da Sociedade Ginástica de } \\
\text { Hamburgo Velho e o Casarão das Artes. } \\
\text { Enigma - Quais são os ingredientes do Spritzbier? } \\
\text { (os enigmas ficam escondidos atrás da foto que corresponde ao Rastro 1. Os } \\
\text { estudantes decidem também colocar pistas falsas atrás de algumas fotos). }\end{array}$ \\
\hline
\end{tabular}




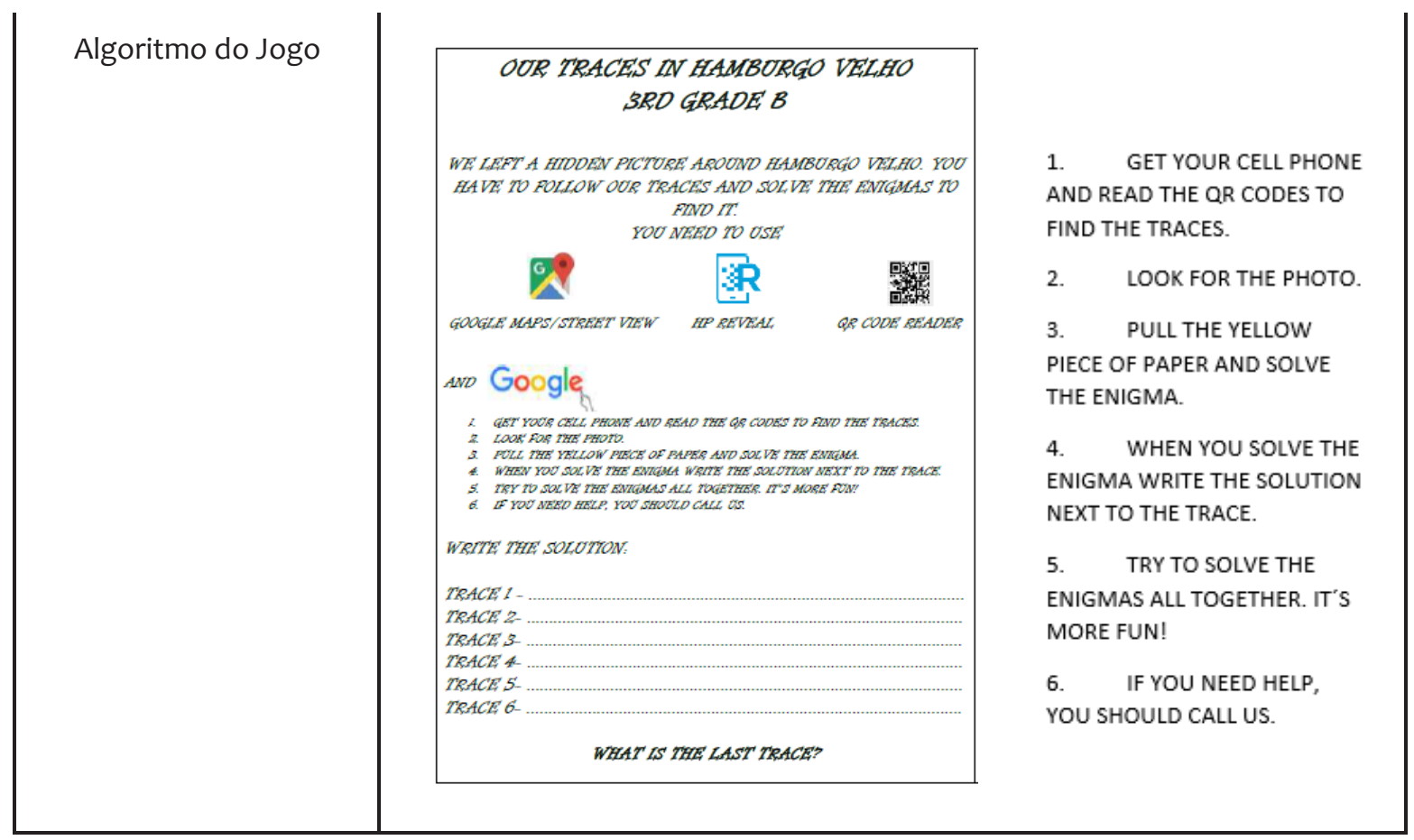

Fonte: elaborado pelos autores.

A Figura 10 contém os rastros construídos pelos estudantes a partir da exploração dos arredores do Centro Histórico de Hamburgo Velho.

Figura 10 - Apresentação dos Rastros construídos pelos estudantes de forma gamificada para os pais
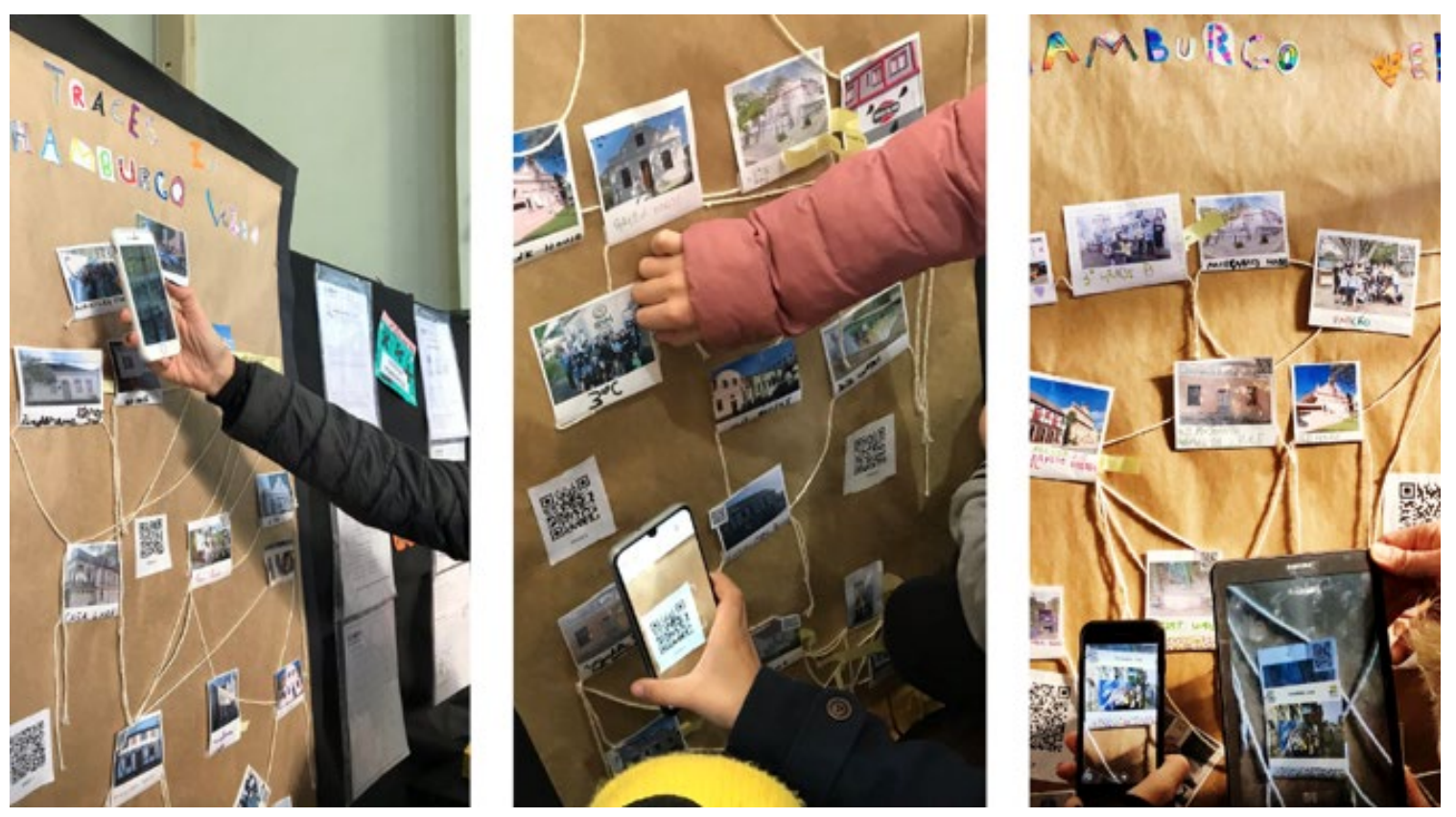

Fonte: elaborado pelos autores. 
A seguir, discutiremos os resultados que emergiram da vivência desta prática pedagógica na cidade.

\section{Resultados}

A partir do método cartográfico de pesquisa-intervenção (PASSOS; KASTRUP; ESCÓSSIA, 2015), apresentamos os analisadores para discutir os resultados da experiência pedagógica, isto é, a experiência em movimento na cidade, os pilares do pensamento computacional em fluxo, os bugs como potência para a invenção, o engajamento e o amadurecimento das relações no grupo de estudantes.

A experiência em movimento com e na cidade trouxe a atenção dos estudantes para elementos da arquitetura e da arte entrelaçados com a história e a cultura do bairro. Tal interesse potencializou a emersão de um sentimento de pertencimento, por haver espaços em melhor estado de conservação do que outros, o que gerou questionamentos entre os estudantes, bem como e-mail, enviado à comunidade luterana, com sugestões para reabertura da Gemeindeschule. Essas incursões produziram experiências ricas de descobertas, de significação e ressignificação de lugares, ampliando a percepção e interpretação dos espaços. Ao discutirmos a respeito, as falas predominantes dos estudantes estavam relacionadas às ruas, aos trajetos, à arquitetura e à história como "eu estou aprendendo sobre as ruas e os lugares”, “eu aprendi que Hamburgo Velho é um bairro histórico", "agora eu sei o que é enxaimel”, “eu sei ir sozinho até o museu”, "como as pessoas tem histórias pra contar". Isto nos faz constatar o quanto andar pela cidade, entender como chegar em determinado lugar, nomear os espaços, organizar uma rota, contribuiu para que os estudantes se reconhecessem como parte do território, entendendo-o como algo vivo e estabelecendo relações de afeto com a cidade. As diversas caminhadas pela cidade nos convidam, conforme La Rocca (2018), à exploração, à aventura, ao passeio e ao mergulho na efervescência efêmera de suas ruas. Nesta experiência, por meio da atenção em suspensão (PASSOS; KASTRUP; ESCÓSSIA, 2015), espaços como o Parque Luiz Henrique Roessler, unidade de Conservação Ambiental da cidade, e a Casa da Lyra, uma das casas mais antigas, com uma arquitetura peculiar e habitada por uma artista do bairro, fossem espaços visibilizados pelos estudantes, que lhes 
aguçaram a curiosidade, de maneiro que outros movimentos cartográficos emerjam nos desdobramentos futuros do projeto.

A construção de trajetos pelos estudantes, a partir de pontos localizados no mapa e da resolução dos enigmas, assemelha-se à Geometria da Tartaruga de Papert (1980), experiências em que os estudantes precisavam criar uma sequência, calcular os passos e transforma-los em texto (move forward/turn left/turn right). Contudo, para criar o algoritmo dos trajetos, a partir do movimento pelas ruas da cidade, perceberam ser necessário decompor as rotas, quando decidiam "Vamos até a placa de rua e paramos", ou "Quando a gente chegar naquela esquina, a gente continua a montar.”. A decomposição requer pensar subprocedimentos (PAPERT, 1980), elemento importante para construção do algoritmo, o qual, aqui, na experiência com cidade, entende-se como a parte que está no todo e o todo que está na parte (MORIN, 2011). Ser a "tartaruga" na cidade é se descobrir acoplado ao lugar que os provoca a pensar e problematizar, atuar juntos na experiência do movimento, pensar em trajetos, direções, deslocamentos, formas, cartografias.

Os espaços da cidade podem se tornar recognitivos para nós, visto que as incursões pelas ruas do bairro percorreram trajetos familiares. Segundo Lemos (2013), existe o espaço genérico da cidade e os lugares que assinamos, isto é, aqueles pelos quais passam nossa experiência recognitiva. A construção das rotas envolve repetição de movimentos e reconhecimento de padrões. Tal reconhecimento contribuiu para que, ao depararem novos enigmas que demandaram construção de novos percursos, os estudantes compreendessem haver um padrão, embora determinada parte se modificasse conforme a situação. Semelhantemente ocorreu ao precisarem armar o cálculo da subtração com milhar do ano de construção das casas. Mesmo sem ter a mesma experiência na escola, a necessidade de calcular a idade das casas possibilitou o reconhecimento do padrão de cálculo da centena, usado para resolver o enigma da idade da casa. Portanto, evidenciouse novamente o quanto a cidade é território rico para invenção de práticas pedagógicas. O reconhecimento de padrões, entendido pela perspectiva da aprendizagem inventiva, traduz-se como cultivo, não apenas repetição mecânica (KASTRUP, 2010; 2015), mas atividade criadora, pois, as várias incursões pela cidade, ao produzirem familiaridade, geraram acoplamentos que superam a noção de aprendizagem como aquisição de 
informações, e contribuíram para a construção do próprio jogo de rastros pelos estudantes, posteriormente.

A criação, pelos estudantes, do seu próprio jogo de rastros, tornou a experiência com a cidade mais abrangente, por ser necessário o processo de abstração (PAPERT, 1994; WING, 2017) para isolar do espaço genérico da cidade os locais, as vivências mais significativas, e definir padrões, destacar determinadas experiências entre muitas. Envolvia pensar a parte e o todo em sinergia, pois, ao desenvolver o jogo, os estudantes, a partir do que viveram, criaram a narrativa e a missão, elegeram rastros, escolheram tecnologias, definiram enigmas e "executaram" a mecânica e dinâmica do jogo por meio de uma sequência de procedimentos (algoritmo) materializados de forma textual. Este processo, ocorrido semanas após a prática pedagógica pela cidade, trouxe as famílias para a experiência com a cidade.

Um dos pais relatou o seguinte: "Minha filha só fala em Hamburgo Velho. Às vezes, quando sai do carro, diz 'Casa do Solado is next to Pindorama. Move forward and turn right. Eu fico impressionada. A gente tá andando de carro e ela fica dando as direções". Isto demonstram o sentimento de vínculo, de conhecimento da cidade, bem como a forma algorítmica de interpretar os movimentos.

As epistemologias reticulares e conectivas, a aprendizagem e a metodologia inventiva PAG nos ajudam a refletir sobre a compreensão do pensamento computacional além da resolução de problemas, de forma ampla, a partir de problematizações que emergiram dos agenciamentos entre os estudantes, a arte, a arquitetura, os moradores, as ruas e a história durante as vivências das práticas pedagógicas.

Tais problematizações constituem rupturas, breakdowns, e levaram à experiência da invenção, da imprevisibilidade, pois, "a descoberta não pode ser preparada, a invenção não pode ser planejada" (PAPERT, 1980, p. 143). Inventar é garimpar algo oculto, mas que se revela. Aqui, a experiência de transitar pela cidade atrás de um objeto misterioso através de rastros, da resolução de enigmas, de caminhos planejados em um mapa, levam a constantes situações de tensionamento entre saberes anteriores e uma falta de prontidão diante de problema novo, um "bug" que emerge e perturba.

Para Papert (1980, p. 142), na linguagem computacional, os bugs são benéficos porque "eles nos levam a estudar o que aconteceu, a entender o que aconteceu de errado, e através do entendimento, corrigi-los". Na aprendizagem inventiva, entendemos que os 
bugs são as próprias rachaduras, os breakdowns; "Deu bug", costumavam dizer os estudantes quando algo inusitado acontecia. A experiência de criação do jogo de rastros para as famílias fez surgirem muitas rupturas, pois, ao testarem os rastros, os enigmas, as tecnologias, os alunos se deparavam com bugs em procedimentos que não estavam claros o suficiente e precisavam de reformulação, como algumas pistas que não levavam ao rastro esperado, de modo que os $Q R$ Codes deveriam ser corrigidos.

Deparar-se com um bug gerava estranhamento e tencionava o saber anterior (o que foi planejado) e a experiência atual (o que não consegue ser executado). Portanto, os bugs são signos que forçavam a construir uma maneira de organizar o pensamento para realizar a atividade. Desenvolver o pensamento computacional é ser sensível aos signos dos bugs. Segundo Kastrup (2001, p. 20) “quando somos tocados pelo signo, pela diferença, temos uma experiência de problematização, de invenção do problema".

A opção por conceber esta prática pedagógica no âmbito da metodologia inventiva Projeto de Aprendizagem Gamificado — PAG (SCHLEMMER, 2014; 2015; 2016a; 2016b; 2018), gerou maior engajamento dos estudantes, ao se depararem com elementos presentes em jogos conhecidos por eles, como Pokémon, por exemplo, que fazem parte do seu cotidiano. Além disso, desenvolver projetos, conforme Schlemmer (2018), é atividade que requer trabalhar com o outro em colaboração, e em todas as situações de aprendizagem os estudantes precisavam se ajudar mutuamente instigados pelos desafios, pelas missões e pelas descobertas. Entre os estudantes, destacou-se a oportunidade que o projeto gamificado ofereceu de poder "sair da escola", "caçar coisas", "aprender muito sobre Hamburgo Velho”, "descobrir coisas sobre o passado da escola e de Hamburgo Velho", “quero fazer mais atividades assim", bem como "a gente aprende a trabalhar em grupo" e "brigar não é legal”. Constatou-se que, como as saídas pela cidade se tornaram parte da rotina, bem como as missões eram desenvolvidas em grupo, os estudantes encontraram formas de resolver conflitos com mais autonomia.

A prática pedagógica gamificada na cidade, descrita neste texto como parte do conjunto de práticas que compõem o projeto Traces in Hamburgo Velho, possibilitou experiências de conhecimento da, na e com a cidade, fornecendo pistas para compreender como o coengendramento entre humanos e não humanos produz o pensamento computacional na perspectiva da aprendizagem inventiva. 
A discussão neste artigo pretendeu ir além de adequar conceitos de programação à realidade, entendendo a cidade como espaço vivo, comunicativo, que influencia nossa forma de sentir, proporciona diversas possibilidades de significação e interpretação: "estou aprendendo a conhecer as ruas e fazer caminhos pela cidade com estas atividades, este é o nosso Code", disse um dos alunos.

\section{CONSIDERAÇÕES FINAIS}

O presente texto visou apresentar, analisar e discutir os dados produzidos de uma prática docente desenvolvida no território da cidade, vinculados ao desenvolvimento do pensamento computacional, à aprendizagem inventiva, à hibridação de espaços urbanos e pós-urbanos em um habitar do ensinar e aprender conectados com a vida na perspectiva de uma Educação OnLIFE. A prática docente possibilitou transcender os espaços físicos da escola e permitir a construção de outros espaços e situações de aprendizagem entre pesquisadores, estudantes e a cidade, sem o dualismo e off-line/on-line, em um coengendramento entre atores humanos e não humanos.

A realidade atual demanda mais que resolver problemas, implica problematização do mundo presente, que gera rachaduras, breakdowns. Habitamos redes cada vez mais dinâmicas, em um novo contexto ecológico, digitalizado, composto não apenas por humanos, mas também, segundo Schlemmer, Felice e Serra (2020), pela biodiversidade, pelos algoritmos e dados. Compreendemos que o pensamento computacional precisa ser desenvolvido a partir desta problematização, para conectar as diversas entidades que habitam os espaços e superar a perspectiva antropocêntrica. Se humanos e não humanos habitam os espaços, o pensamento computacional produzido de tal coengendramento estimula um diálogo entre os entes envolvidos, possibilitando entender a cidade como território educativo, vivo, comunicativo, despertando também afetos e sentimentos de pertencimento.

Segundo Kastrup (2015), o mundo contemporâneo perturba, e aprender a viver em um mundo sem fundamentos é inventá-lo ao viver. Para tanto, precisamos de experiências de Educação, conectadas com a vida.

\section{REFERÊNCIAS}


BRASIL. Ministério da Educação. Base Nacional Curricular Comum. Brasília: MEC, 2017. Disponível em: http://basenacionalcomum.mec.gov.br/. Acesso em: 23 ago. 2021.

DELEUZE, Gilles; GUATTARI, Félix. Mil Platôs: capitalismo e esquizofrenia. Rio de Janeiro: Editora 34, 1995. v. 1. (Trans).

DI FELICE, Massimo. Depois da metrópole, as redes info-ecológicas e o fim da experiência urbana. Revista de Comunicação e Linguagens, Lisboa, n. 48, 2018. Disponível em: https://rcl.fcsh.unl.pt/index.php/rcl/article/view/67. Acesso em: 23 ago. 2021.

DI FELICE, Massimo. Paisagens pós-urbanas: o fim da experiência urbana e as formas comunicativas do habitar. São Paulo: Annablume, 2009.

DI FELICE, Massimo. Redes sociais digitais, epistemologias reticulares e a crise do antropomorfismo social. Revista USP, São Paulo, n. 92, p. 6-19, 2012. DOI https://doi.org/10.11606/issn.2316-9036.voig2p6-19

FLORIDI, Luciano. The onlife manifesto: being human in a hyperconnected era. Berlin: Springer International Publishing, 2015.

ISTE/CSTA. Computational Thinking Teacher Resource. 2. ed. 2011. Disponível em: http://csta.acm.org/Curriculum/sub/CurrFiles/472.11CTTeacherResources_2ed-SP-vF.pdf. Acesso em: 23 ago. 2021.

KASTRUP, Virgínia. Aprendizagem, arte e invenção. Psicologia em Estudo, Maringá, v. 6, n. 1, p. 17-27, 2001. Disponível em:

https://www.scielo.br/j/pe/a/NTNFsBzXts5GHp4Zk8sBbyF/?lang=pt\&format=pdf. Acesso em: 23 ago. 2021.

KASTRUP, Virginia. Experiência estética para uma aprendizagem inventiva: notas sobre o acesso de pessoas cegas a museus. Informática na educação: teoria \& prática, Porto Alegre, v. 13, n. 2, 2010. DOI https://doi.org/10.22456/1982-1654.12463

KASTRUP, Virgínia. O devir-criança e a cognição contemporânea. Psicologia: reflexão e crítica, Porto Alegre, v. 13, n. 3, p. 373-382, 2000. DOI https://doi.org/10.1590/S010279722000000300006

KASTRUP, Virginia. Pista 2: O funcionamento da atenção no trabalho do cartógrafo. In: KASTRUP, Vírginia; TEDESCO, Silvia; PASSOS, Eduardo. Políticas da cognição. Porto Alegre: Sulina, 2015.

KASTRUP, Virgínia. Políticas cognitivas na formação do professor e o problema do devirmestre. Educação \& Sociedade, Campinas, v. 26, n. 93, p. 1273-1288, 2005. DOI https://doi.org/10.1590/S0101-73302005000400010

KASTRUP, Virgínia et al. A invenção de si e do mundo: uma introdução do tempo e do coletivo no estudo da cognição. São Paulo: Autêntica, 1999. 
PASSOS, Eduardo; KASTRUP, V.; ESCÓSSIA, Liliana da. Pistas do método da cartografia: pesquisa-intervenção e produção de subjetividade. Porto Alegre: Sulina, 2010. v. 1. p. 3251.

LA ROCCA, Fabio. A cidade em todas as suas formas. Trad. Adriana Anunciação Ramos. Porto Alegre: Sulina, 2018. 279 p.

LA ROCCA, Fabio. Ambiências climatológicas urbanas: pensar a cidade pós-moderna. Comunicação e Sociedade, São Paulo, v. 18, p. 157-164, 2010. DOI https://doi.org/10.17231/comsoc.18(2010).994

LA ROCCA, Fabio. Territórios híbridos: conectividade e experiências comunicativas tecnometropolitanas. Revista FAMECOS: mídia, cultura e tecnologia, Porto Alegre, v. 23, n. 3, sept.-dic. 2016. DOI http://dx.doi.org/10.15448/1980-3729.2016.3.24817

LEMOS, André. A comunicação das coisas. Teoria ator-rede e cibercultura. São Paulo: Annablume, 2013.

LEMOS, André. Celulares, funções pós-midiáticas, cidade e mobilidade. Revista Brasileira de Gestão Urbana, Curitiba, v. 2, n. 2, p. 155-166, 2017. Disponível em: https://periodicos.pucpr.br/index.php/Urbe/article/view/5344. Acesso em: 23 ago. 2021.

LEMOS, André. Cibercidade: as cidades na cibercultura. Rio de Janeiro: E-papers, 2004.

LEMOS, André. Cidade e mobilidade. Telefones celulares, funções pós-massivas e territórios informacionais. Matrizes, São Paulo, v. 1, n. 1, p. 121-137, 2007. DOI https://doi.org/10.11606/issn.1982-8160.v111p121-137

LOPES, Daniel; SCHLEMMER, Eliane. A cultura digital nas escolas: para além da questão do acesso às tecnologias digitais. 2011. Disponível em:

http://abciber.org.br/simposio2011/anais/Trabalhos/artigos/Eixo\%201/9.E1/365-591-1-RV.pdf. Acesso em: 23 ago. 2021.

MATURANA, Humberto; VARELA, Francisco; DOS SANTOS, Jonas Pereira. A árvore do conhecimento: as bases biológicas do entendimento humano. Campinas: Editorial Psy, 1995.

MOREIRA, José António; SCHLEMMER, Eliane. Por um novo conceito e paradigma de educação digital onlife. Revista uFG, Goiânia, v. 20, p. 1-35, 2020. DOI

https://doi.org/10.5216/revufg.v20.63438

MORIN, Edgar. Introdução ao pensamento complexo. Porto Alegre: Sulina, 2011.

NÓVOA, António et al. Pesquisa em educação como processo dinâmico, aberto e imaginativo: uma entrevista com António Nóvoa. Educação \& realidade, Porto Alegre, v. 36, n. 2, p. 543-533, 2011. Disponível em:

https://www.redalyc.org/articulo.oa?id=317227057004. Acesso em: 23 ago. 2021.

PAPERT, Seymour A. A máquina das crianças: repensando a escola na era da informática. Porto Alegre: Artes Médicas, 1994. 
PAPERT, Seymour A. Mindstorms: Children, computers, and powerful ideas. New York: Basic Books, 1980.

PAPERT, Seymour A.; SOLOMON, Cynthia. Twenty things to do with a computer. MIT, 1972. Disponível em: http://www.stager.org/articles/twentythings.pdf. Acesso em: 23 ago. 2021.

PASSOS, Eduardo; KASTRUP, Virgínia; ESCÓSSIA, Liliana da. Pistas do método da cartografia: pesquisa-intervenção e produção de subjetividade. Porto Alegre: Sulina, 2009.

PASSOS, Eduardo; KASTRUP, Virgínia; ESCÓSSIA, Liliana da. Pistas do Método da Cartografia - Pesquisa: intervenção e produção de subjetividade. Porto Alegre: Sulina, 2015. v. 1.

RAABE, André Luís Alice; BRACKMANN, Christian Puhlmann; CAMPOS, Flávio Rodrigues. Currículo de Referência em Tecnologia e Computação: da Educação Infantil ao Ensino Fundamental. 2. ed. São Paulo: CIEB, 2020. Disponível em https://curriculo.cieb.net.br/assets/docs/Curriculo-de-referencia_El-e-EF_2aedicao_web.pdf. Acesso em: 23 ago. 2021.

SCHLEMMER, Eliane. A cidade como espaço de aprendizagem: games e gamificação na constituição de Espaços de Convivência Híbridos, Multimodais, Pervasivos e Ubíquos para o desenvolvimento da Cidadania. Relatório de pesquisa. 2020.

SCHLEMMER, Eliane. Games e Gamificação: uma alternativa aos modelos de EaD. Revista Iberoamericana de Educación a Distancia, Madrid, v. 19, n. 2, p. 1-12, 2016b. DOI https://doi.org/10.5944/ried.19.2.15731

SCHLEMMER, Eliane. Gamificação em contexto de hibridismo e multimodalidade na educação corporativa. Revista FGV Online, v. 5, p. 26-49, 2015. Disponível em: https://www.researchgate.net/publication/350290205_Gamificacao_em_contexto_de_hi bridismo_e_multimodalidade_na_educacao_corporativa_-_REVISTA_FGV. Acesso em: 23 ago. 2021.

SCHLEMMER, Eliane. Gamificação em espaços de convivência híbridos e multimodais: design e cognição em discussão. Revista da FAEEBA - Educação e Contemporaneidade, Salvador, v. 23, n. 42, p. 73-89, 2014. DOI 10.21879/faeeba2358-0194.2014.v23.n42.p\%p

SCHLEMMER, Eliane. Hibridismo, Multimodalidade e Nomadismo: codeterminação e coexistência para uma Educação em contexto de ubiquidade. In: MILL, Daniel; REALI, Aline (orgs.). Educação a distância, qualidade e convergências: sujeitos, conhecimentos, práticas e tecnologias. 1. ed. São Carlos: EdUFSCar, 2016a. v. 1. p.1-24.

SCHLEMMER, Eliane. Projetos de aprendizagem gamificados: uma metodologia inventiva para a educação na cultura híbrida e multimodal. Momento-Diálogos em Educação, Rio Grande, v. 27, n. 1, p. 42-69, 2018. DOI https://doi.org/10.14295/momento.v27i1.7801 
SCHLEMMER, Eliane; DI FELICE, Massimo; SERRA, Ilka. Educação OnLIFE: a dimensão ecológica das arquiteturas digitais de aprendizagem. Educar em Revista, Curitiba, v. 36, n. 1, p. 1-22, 2020. DOI: http://dx.doi.org/10.1590/0104-4060.76120

SCHLEMMER, Eliane; OLIVEIRA, Lisiane; MENEZES, Janaína. O habitar do ensinar e do aprender em tempos de pandemia e a virtualidade de uma educação OnLIFE. Práxis Educacional, v. 17, n. 45, p.1-25, 2021. DOI: https://doi.org/10.22481/praxisedu.v17i45.8339

SOCIEDADE BRASILEIRA DE COMPUTAÇÃO (SBC). Diretrizes para o Ensino de Computação na Educação Básica. $1^{\circ}$ nov. 2019. Disponível em: https://www.sbc.org.br/educacao/diretrizes-para-ensino-de-computacao-na-educacaobasica. Acesso em: 23 ago. 2021.

THE ROYAL SOCIETY. Shut down or restart? The way forward for computing in UK Schools. London: Excellence in Science, 2012. Disponível em: https://royalsociety.org/ /media/education/computing-in-schools/2012-01-12-computing-inschools.pdf. Acesso em: 23 ago. 2021.

USA NATIONAL RESEARCH COUNCIL. Report of a Workshop on the Scope and Nature of Computational Thinking 2010. Washington: The National Academies Press, 2010.

Disponível em: http://www.nap.edu/catalog.php?record_id=12840. Acesso em: 23 ago. 2021.

WING, Jeannette. Computational thinking and thinking about computing. Philosophical transactions of the royal society of London A: mathematical, physical and engineering sciences, v. 366, n. 1881, p. 3717-3725, 2008. DOI https://doi.org/10.1098/rsta.2008.0118

WING, Jeannette. Computational thinking. Communications of the ACM, v. 49, n. 3, p. 3335, 2006. DOI doi>10.1145/1118178.1118215

WING, Jeannette. Computational thinking's influence on research and education for all. Italian Journal of Educational Technology, Gênova, v. 25, n. 2, p. 7-14, 2017. DOI $10.17471 / 2499-4324 / 922$

WING, Jeannette. Computational Thinking: what and why. Thelink. 2011. Disponível em: https://www.cs.cmu.edu/link/research-notebook-computational-thinking-what-and-why. Acesso em: 23 ago. 2021.

WING, Jeannette; STANZIONE, Dan. Progress in computational thinking, and expanding the HPC community. Communications of the ACM, [s.I.], v. 59, n. 7, p. 10-11, 2016. DOI doi $>10.1145 / 2933410$ 